\title{
Chemical Characterization of Gilsonite Bitumen
}

\author{
Nader Nciri', Suil Song ${ }^{1}$, Namho Kim ${ }^{2}$ and Namjun $\mathrm{Cho}^{1 *}$
}

${ }^{1}$ Department of Energy, Materials and Chemical Engineering, Korea University of Technology and Education, 1600 Chungjeol-ro, Byeongcheon-myeon, Dongnam-gu, Cheonan-City, Chungnam Province 330-708, Republic of Korea

${ }^{2}$ Department of Architectural Engineering, Korea University of Technology and Education, 1600 Chungjeol-ro, Byeongcheon-myeon, Dongnam-gu, Cheonan-City, Chungnam Province 330-708, Republic of Korea

\begin{abstract}
This research provides new insights into the chemical composition of the Gilsonite in order to ascertain its properties which can assist in the refining and processing paths of the natural resource. Gilsonite, naturally occurring asphaltite bitumen, consists of a complex mixture of organic compounds. It was collected in the Uinta Basin near the town of Bonanza, Utah. The aim of this work is to obtain a more complete picture of molecular structure of Gilsonite, very important in fuel processing industry, matching and interpreting the results from different techniques. The Gilsonite was characterized by elemental analysis $(E A)$ to determine the concentrations of $\mathrm{C}, \mathrm{H}, \mathrm{N}, \mathrm{S}$, and $\mathrm{O}$, by Fourier transform infrared spectroscopy (FTIR) for comparative analysis of the chemical structures, by Nuclear magnetic resonance spectroscopy of hydrogen $\left({ }^{1} \mathrm{H} \mathrm{NMR}\right)$ to ascertain the aliphatic and aromatic hydrogen fractions, and by Thin layer chromatography-flame ionization detection (latroscan TLC-FID) to quantify saturated and aromatic hydrocarbons, and resin/asphaltene fractions. The results were evaluated in combination with the available geological data and with some bitumens to evaluate, chemically, possible mechanisms of Gilsonite formation. Low hydrogen to carbon atomic ratio (1.44), low sulfur $(0.27 \mathrm{wt} . \%)$ and high nitrogen (3.25 wt.\%) contents were the main characteristics of the Gilsonite from Uinta Basin. FTIR revealed the presence of alkane, aromatic rings, phenyl rings, alcohols, carbonyl groups, organic sulfoxides, and sulfate salts, confirming the fact that Gilsonite is composed of high molecular weight polycyclic constituents comprising of nitrogen, sulfur and oxygen heteroatoms. Likewise, FTIR proved that Gilsonite includes fingerprint of clay minerals. latroscan data showed interestingly that Gilsonite contains considerable amount of asphaltenes (79.7 wt.\%) and nil amount of aromatics ( $0 \mathrm{wt} . \%)$. While, the yields of saturates and resins account only for $1.6 \mathrm{wt} . \%$ and $18.7 \mathrm{wt} . \%$, respectively. Furthermore, SARA method estimated that Gilsonite is extremely instable (Colloidal instability index, $\mathrm{Cll}=4.34$ ). Proton NMR measurements indicated that the aliphatic hydrogen portion is approximately $95.38 \%$ and the aromatic hydrogen fraction is about $4.62 \%$.
\end{abstract}

Keywords: Gilsonite; Uintaite; Asphaltite; Natural bitumen; Elemental analysis; FTIR spectroscopy; Iatroscan TLC-FID; Colloidal instability index; ${ }^{1} \mathrm{H}$ NMR spectroscopy

\section{Introduction}

Many regions and individual countries have to solve a problem of future growth of power demand while their own sources of feedstock are limited. One of possible alternatives can be found in West America where one of the world's remarkable vein deposits of several types of solid hydrocarbons are located in the Uinta basin of northeastern and north-central Utah. By far the most important of these is Gilsonite. Gilsonite, originally known as "Uintaite" is a natural, high purity, solid hydrocarbon rich in asphaltenes and nitrogen compounds. It is glossy black and brittle and contains little sulfur or ash [1,2]. Although it appears similar to hard coal or asphalt, its chemical properties are significant different. It is classified as an asphaltite. Gilsonite is soluble in aromatic and aliphatic solvents, as well as petroleum asphalt. Due to its unique compatibility, Gilsonite is frequently used to harden softer petroleum products. The Gilsonite occurs in parallel, nearvertical fractures in the Uinta Formation of the Uinta Basin of Utah and Colorado. The Green River Formation also contains rich oil shales that may have been the source of the hydrocarbons that formed the Gilsonite. The Gilsonite-bearing factures often outcrop and may be as much as 2,000 feet deep. They vary in width from a few inches to 22 feet and may be as long as 25 miles. Average vein thickness is 6 feet, but veins as thin as 18 inches have been mined. It is believed that these factures were once filled with a heavy, viscous crude oil that lost of its volatile constituents and then solidified [1,3,4]. Gilsonite, named after Samuel H. Gilson, was discovered in the 1860s. Gilson was not one of the original discovers of Gilsonite, but his enthusiastic development and promotional efforts linked the material to him, and people in the region began refereeing to this material as Gilsonite rather than using its scientific name, "Uintaite" [5,6]. The name Gilsonite further solidified in common usage when an early mining company adopted and trademarked the name. Much Gilsonite is used directly in its crude form, as insulation for pipelines, particularly hot pipes, as waterproofing and undercoating for wood and metal, and as paving, roofing and other uses identical with crude asphalt. Gilsonite is also blended with refinery produced asphalt and petroleum products to obtain certain desired characteristics. It is used in saturating felts and building construction papers [7]. As underlined previously, the world energy demand is expected to increase due the expanding urbanization, better living standards and increasing population. At a time when society is becoming increasingly aware of the declining reserves of fossil fuels beside the environmental concerns, it has become apparent that Gilsonite is destined to make a substantial contribution to the future energy demands of the domestic and industrial economies. In this way,

*Corresponding author: Namjun Cho, Department of Architectural Engineering, Korea University of Technology and Education, 1600 Chungjeol-ro, Byeongcheonmyeon, Dongnam-gu, Cheonan-City, Chungnam Province 330-708, Republic of Korea, Tel.: 82-10-3913-2725; E-mail: njuncho@koreatech.ac.kr

Received March 25, 2014; Accepted September 26, 2014; Published October 20, 2014

Citation: Nciri N, Song S, Kim N, Cho N (2014) Chemical Characterization of Gilsonite Bitumen. J Pet Environ Biotechnol 5: 193. doi:10.4172/21577463.1000193

Copyright: (c) 2014 Nciri N, et al. This is an open-access article distributed under the terms of the Creative Commons Attribution License, which permits unrestricted use, distribution, and reproduction in any medium, provided the original author and source are credited. 
more details about the chemical composition of Gilsonite are required in order to achieve a better exploitation of this natural bitumen deposit. Therefore, the principal goal of this paper was to characterize the Gilsonite using classical analytical methods such as Elemental analysis (EA), Fourier transform infrared spectroscopy (FTIR), Thin layer chromatography-flame ionization detection (Iatroscan TLC-FID), and Hydrogen nuclear magnetic resonance spectroscopy ( ${ }^{1} \mathrm{H}$ NMR).

Gilsonite is special product of ATDM for the mineral known as asphaltum, uintaite, Natural bitumen, mineral tar, natural asphalt,

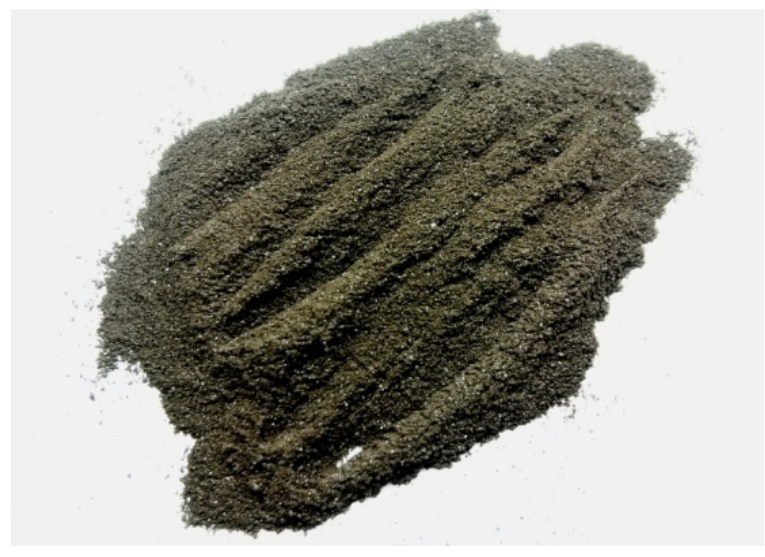

Figure 1: Gilsonite.

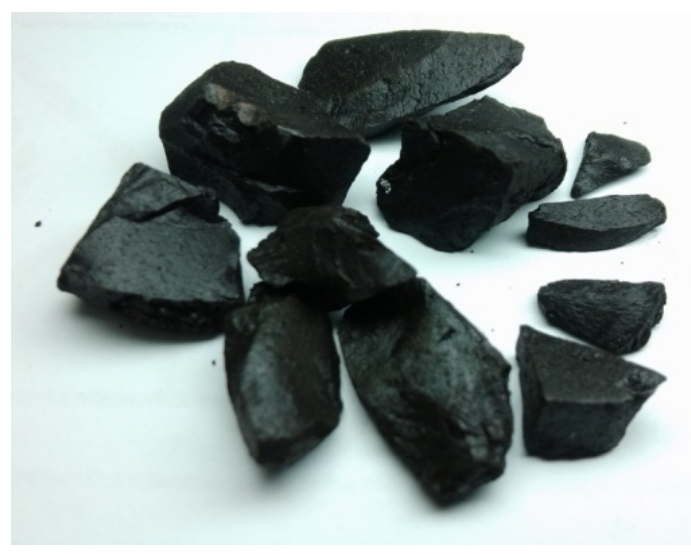

Figure 2: Trinidad Lake Asphalt (TLA).

\begin{tabular}{|c|c|}
\hline Parameters & Conditions \\
\hline Temperature & $25^{\circ} \mathrm{C}$ \\
\hline Pulse flip angle & $45.0^{\circ}$ \\
\hline Acquisition time & $2.55 \mathrm{~s}$ \\
\hline Relaxation delay time & $5.00 \mathrm{~s}$ \\
\hline Number of scans & 256 \\
\hline Sweep width & $6410.3 \mathrm{~Hz}$ \\
\hline FT size & 32768 points complex \\
\hline Carrier frequency & $399.8372832 \mathrm{MHz}$ \\
\hline Total scan time & $32 \mathrm{~min}$ \\
\hline Solvent & $\mathrm{CDCl}$ \\
\hline Reference & $\mathrm{TMS}$ \\
\hline
\end{tabular}

Table 1: Conditions for ${ }^{1} \mathrm{H}$ NMR measurements. mineral bitumen, bitumen powder, drilling mud, or uintahite, which is found in commercial quantities only in the Utah of USA and Kermanshah of Iran. This unique mineral is used in more than 160 products, primarily in dark-colored printing inks and paints, oil well drilling muds and cements, asphalt modifiers, foundry sands additives and a wide variety of chemical products.

\section{Experimental}

\section{Geological setting}

In this research, Gilsonite from Uintah Basin mines in northeastern Utah, USA, was selected. It consisted of two materials, including the asphalt and mineral aggregate. Gilsonite was a shiny, black substance similar in appearance to the mineral obsidian. It was brittle and can be easily crushed into a dark brown powder (Figure 1). In order to enable a more comprehensive discussion of the results, reference was made to other natural bitumen from the Pitch Lake in Trinidad Island: Trinidad Lake Asphalt (TLA) (Figure 2). TLA was dark-brown colored cementitious substance. It was brittle and broke into small cellular glossy fragments. All samples were analyzed by the same techniques to provide directly comparable geochemical information.

\section{Analytical procedure}

Fourier-transferred infrared spectroscopy: FTIR spectra were collected with A Perkin Elmer Spectrum RX IFT-IR system equipped with MIRacle ${ }^{\mathrm{TM}}$ attenuated total reflectance (ATR) cell from Pike Technologies. The instrument's resolution was $2 \mathrm{~cm}^{-1}$. The spectra were recorded in the range $4000-650 \mathrm{~cm}^{-1}$ and represent the averaging of 32 scans collected at intervals of $1 \mathrm{~cm}^{-1}$.

Elemental analysis: Determination of carbon, hydrogen, nitrogen, oxygen and sulfur contents of bitumen were carried out using a Thermo Scientific Flash 2000 HT, Elemental Analyzer (UK).

${ }^{1} \mathrm{H}$ NMR spectroscopy: The ${ }^{1} \mathrm{H}$ NMR spectra of bitumens were performed on VNMRS-400 spectrometer (Agilent Technologies Korea Ltd., Seoul, Korea) operating at $9.4 \mathrm{~T}$, using a $5 \mathrm{~mm}$ Broadband ${ }^{1} \mathrm{H} / \mathrm{X} / \mathrm{D}$ NMR probe. The ${ }^{1} \mathrm{H}$ NMR experiments were performed, using $20 \mathrm{mg}$ of bitumen diluted in $0.6 \mathrm{~mL}$ of a solution of $50 \mathrm{mM}$ of $\mathrm{Cr}(\mathrm{acac})_{3}$ in deuterated chloroform. Tetramethylsilane was used to reference the chemical shift. The experimental conditions are given in Table 1.

\section{SARA TLC-FID}

An Iatroscan MK-6 \& 6s instrument (Iatron Labs. MCMC Corporation, Tokyo), equipped with a flame ionization detector (FID) and interfaced with a computerized acquisition system (DIONEX AI 450 Optimize) was employed. This instrument was calibrated for quantitative SARA analysis. Pure hydrogen $\left(160 \mathrm{~mL} \mathrm{~min}^{-1}\right.$ supplied by a hydrogen generator) and pure air $\left(2.0 \mathrm{~L} \mathrm{~min}^{-1}\right)$ supplied by an air cylinder) were used for the detector. Two sets of 10 silica rods, type Chromarod-SIII (pore diameter $60 \AA$, particle size $5 \mu \mathrm{m}$ ) were used: One for the saturate and aromatic quantification and the other one for asphaltene quantification. Samples were prepared by dissolution in dichloromethane to obtain a final concentration of $10-15 \mathrm{mg} \mathrm{mL}^{-1}$. Before sample application, Chromarods were passed twice through the FID to remove contaminants, and to obtain constant activity of the silica layer. Each rod was spotted by $0.1 \mu \mathrm{L}$ of the sample solution, applied dropwise by using a $1.0 \mu \mathrm{L}$ syringe. For saturate and aromatic determinations, Chromarods were developed in $n$-hexane for 30 min; air dried $(3 \mathrm{~min})$ and developed again in toluene for $18 \mathrm{~min}$. For asphaltene determinations, the second set of Chromarods was developed in dichloromethane /methanol 95:5 vol.\% for $4 \mathrm{~min}$. Each 
Citation: Nciri N, Song S, Kim N, Cho N (2014) Chemical Characterization of Gilsonite Bitumen. J Pet Environ Biotechnol 5: 193. doi:10.4172/21577463.1000193

Page 3 of 10

\begin{tabular}{|c|c|c|c|c|}
\hline \multirow{2}{*}{ Property } & \multicolumn{4}{|c|}{ Bitumens } \\
\hline & Gilsonite & TLA & Petroleum pitch & Oil shale kerogen \\
\hline Carbon, wt.\% & 84.36 & 50.38 & 84.44 & 80.5 \\
\hline Hydrogen, wt.\% & 10.05 & 6.06 & 9.19 & 10.3 \\
\hline Nitrogen, wt.\% & 3.25 & 0.72 & 0.43 & 2.4 \\
\hline Sulfur, wt.\% & 0.27 & 4.14 & 5.69 & 1.0 \\
\hline Oxygen, wt.\% & 1.36 & 4.71 & 3.24 & 5.8 \\
\hline $\mathrm{H} / \mathrm{C}$, atomic ratio & 1.44 & 1.44 & 1.31 & 1.53 \\
\hline $\mathrm{O} / \mathrm{C}$, atomic ratio & 0.01 & 0.07 & 0.02 & 0.05 \\
\hline $\mathrm{C} / \mathrm{N}$, atomic ratio & 39.05 & 104.75 & 305.65 & 50.37 \\
\hline $\mathrm{S} / \mathrm{C}$, atomic ratio & 0.01 & 0.03 & 0.02 & 0.04 \\
\hline Heating value (Btu/Lb) & 17,812 & 10,627 & 17,421 & 17,080 \\
\hline Organic matter, wt.\% & 99.32 & 66.01 & 100 & 100 \\
\hline Inorganic matter, wt.\% & 0.68 & 33.99 & 0 & 0 \\
\hline References & This work & {$[64]$} & [65] & {$[66]$} \\
\hline
\end{tabular}

Table 2: Properties of bitumens.

set of rods was dried for $3 \mathrm{~min}$ and then, pyrolized at a scan speed of $0.32 \mathrm{~cm} \mathrm{~s}^{-1}$.

Prediction of Gilsonite stability: The possibility of asphaltene deposition was determined by the SARA method proposed by Gaestel [8]. The SARA method uses Eq. (1) for calculating the colloidal instable index (CII):

$$
C I I=\frac{\mathcal{w}_{\text {saturates }}+\mathcal{w}_{\text {asphaltenes }}}{\mathcal{W}_{\text {resins }}+\mathcal{W}_{\text {aromatics }}}
$$

Where $w$ stands for the mass fraction of saturates, asphaltenes, resins, and aromatics in bitumen, respectively. When the CII value of bitumen is greater than or equal to 0.9 , asphaltene deposition is likely to occur.

\section{Results and Discussion}

Bitumen is a very complex mixture of organic molecules that vary widely in composition, ranging from non-polar saturated hydrocarbons to highly polar and highly condensed aromatic systems. In order to determine this complex chemical composition of bitumen, elemental analysis, FTIR, TLC-FID, and ${ }^{1} \mathrm{H}$ NMR were employed.

\section{Elemental analysis}

The configuration of the internal structure of bitumen is largely determined by the chemical constitution of the molecular species present. Bitumen is a complex chemical mixture of molecules of a predominantly hydrocarbon nature with a minor amount of structurally analogous heterocyclic species and functional groups containing sulfur, nitrogen and oxygen atoms. Bitumen also contains trace quantities of metals such as vanadium, nickel, iron, magnesium and calcium which occur in the form of inorganic slats and oxides or porphyrine statures. In Table 2 , three additional bitumens were selected to provide a comparison of bitumen from the major vein deposits in Uinta Basin (Gilsonite) with Trinidad Lake Asphalt (TLA), petroleum pitch and oil shale kerogen. The detailed analysis will demonstrate later the differences in bitumens and will provide a better understating of the relationship of composition to the gross properties of the bitumen. Foremost, as can be seen from Table 2, Gilsonite yields are ithin the range of literature reported values [7,9-11].

Elemental analysis (EA) gives access to the contents of carbon, hydrogen, sulfur, oxygen, and nitrogen of the considered types of bitumen. According to Table 2, the molecules are predominantly composed of carbon and hydrogen. Whereas, the heteroatoms (nitrogen, sulfur, oxygen) are present in minor amounts. The different bitumens from Uintah Basin and Trinidad Island vary considerably in their chemical properties which provide a means for characterizing and identifying them. Although, there are major differences between the reservoir characteristics of the Gilsonite deposit and Lake Pitch, there is one notable similarity in hydrogen-to-carbon atomic ratio between these two deposits. Gilsonite is characteristically higher in carbon (84.36 wt.\%) and contains about quince as much nitrogen (3.25 wt.\%) but only about one fifteenth as much sulfur (0.27 wt.\%). Oxygen content is variable, and no trends are obvious when comparing one bitumen with another. Comparing the elemental composition of Gilsonite with petroleum pitch and oil shale kerogen, it can be found that an increase in carbon and hydrogen associated with decrease in oxygen and sulfur are the most pronounced change induced by hydrogenation. Furthermore, it can be noticed that Gilsonite is bitumen that approximates the composition of petroleum pitch, possessing same amount of organic material. In addition, as expected, the elemental analyses of Gilsonite are quite similar to those of oil shale kerogen. This is due to the fact that the precursor of Gilsonite is believed to be oil shale kerogen from the Green River formation deep below the Uintah Basin in eastern Utah. Mild thermal reductive degradation of this kerogen and subsequent fractionation as it was geologically squeezed to the surface are believed to be responsible for the formation of the unique deposits we mine today [12]. Of course, the increased $\mathrm{C}$ and $\mathrm{H}$ levels and reduced $\mathrm{O}$ content leads to the Gilsonite bitumen having a much higher energy density than the TLA. Nevertheless, this natural bitumen still contains nitrogen which is much higher (3.25 wt.\%) than that of TLA (0.72 wt.\%), and thus further chemical or physical upgrading is needed if the material is to be used as a transportation fuel or feedstock for the existing refinery equipment.

Carbon: Table 2 illustrates the distribution of carbon fraction in bitumens samples. It is noticeable that Gilsonite is composed chiefly of carbon (84.36 wt.\%). Similar value is reported for petroleum pitch (84.44 wt.\%). Looking closely at the history of Gilsonite and petroleum pitch, it might lead one to think that Gilsonite, during his formation, was subjected to thermogeological and physical treatments (higher pressure) similar to those adapted in the production of petroleum residues, but in different ways. Thereby, this is could explain the close resemblance between Gilsonite and pitch, and more specifically in their hydrocarbon contents. Some geologists suggest that the most likely source for the Gilsonite hydrocarbon was the organic-rich Green River Formation [13].

Hydrogen: Table 2 shows that Gilsonite (10.05 wt.\%) has a relatively 
high concentration of hydrogen in comparison with TLA (6.06 wt.\%). The result is similar to petroleum pitch $(9.19 \mathrm{wt} . \%)$ and oil shale kerogen (10.30 wt.\%). These differences in hydrogen content are principally related to the amount of organic and inorganic fractions in bitumen. Generally, the cracking of any organic molecule requires hydrogen. The more hydrogen a crude oil contains, the more hydrocarbons it can yield during cracking. Because many of the light product molecules are rich in hydrogen, the residual crude oil gradually becomes more aromatic and hydrogen poor as cracking reaction proceeds. Hunt [14] reported that the change from liquid to solid forms of Gilsonite is chiefly a polymerization with loss of hydrogen (probably as water).

Heteroatoms: Transport fuels have strict limitations on sulfur content. In many countries the maximum allowable sulfur content in gasoline and diesel fuel is $10-15 \mu \mathrm{g} \mathrm{g}^{-1}$. This requires extensive desulfurization, since the bitumen contains around 5 wt.\% sulfur, which is an order of magnitude more than benchmark crudes. Although nitrogen and oxygen does not have to be removed to the same level as sulfur, the nitrogen- and oxygen- containing compounds make bitumen more difficult to refine. These heteroatoms contribute to the aggregation behavior of bitumen. It is therefore required to remove most of the heteroatoms from the bitumen [15]. Moreover, the heteroatoms strongly influence functionality and polarity of molecules and, thus, the mechanical behavior of bitumen [16].

Nitrogen: Information about the nitrogen compounds in Gilsonite is needed in order to provide more efficient processes for converting Gilsonite to useful energy with minimum environmental contamination. The results of elemental analysis indicate that Gilsonite has greater nitrogen content (3.25 wt.\%) than oil shale kerogen $(2.4$ wt.\%). A very unique feature of Gilsonite is its high nitrogen content, which is present mainly as pyrrole, pyridine, and amide functional groups. Phenolic and carbonyl groups are also present. The low oxygen content relative to nitrogen suggests that much of the nitrogen has basic functionality. This probably accounts for Gilsonite's special surface wetting properties and resistance to free radical oxidation [17]. The greater nitrogen content may arise from incorporation of nitrogen gas from the air or from temperature effect. The high nitrogen content indicates that proteinaceous material played an important part in the origin of Gilsonite [18]. In his research paper of 1956, McGee [19] proved that Gilsonite is essentially or totally of plant origin. Going further, it has been postulated that Gilsonite has the highest nitrogen content of the Uinta Basin bitumens [14]. As cited previously, nitrogen is derived mainly from proteinaceous material, which is destroyed rapidly during diagenesis. Most high-nitrogen kerogens were therefore deposited under anoxic conditions where diagenesis was severely limited. Because lignins and carbohydrates contain little nitrogen, most terrestrially influenced kerogens are low in nitrogen. Therefore, this fact could explain the low amount of nitrogen found in oil shale kerogen.

Sulfur: Referring to Table 2, it can be said that Gilsonite is characterized by a lower amount of sulfur ( $0.27 \mathrm{wt} . \%)$ compared to TLA (4.14 wt.\%). As outlined in the literature review, sweet crude oil is considered "sweet" if it contains less than $0.5 \%$ sulfur. Sour crude oil is that when it contains total sulfur contents greater than $0.5 \%$ [20]. Sulfur is highly poisonous, cause foul smelling corrosion and plant rusting. Sulfur is one of the major concerns of refineries. Certain crudes evolve hydrogen sulfide, low boiling sulfur compound and decomposition products of heavy sulfur compounds during processing. However, most of the sulfur compounds concentrate in the distillation residue. Alkali washing and hydro treating remove the sulfur in the distillate. Most of the indigenous crudes are free from dissolved $\left(\mathrm{H}_{2} \mathrm{~S}\right)$ sulfur. This implies that Gilsonite seems of good quality than TLA [20]. On this basis, Gilsonite may be considered as a lucrative deal for many manufacturers who want to invest in the field of natural bitumen. Regarding the sulfur concentration in oil shale kerogen (1 wt.\%), it is four times higher than Gilsonite. In fact, kerogen sulfur is derived mainly from sulfate that was reduced by anaerobic bacteria. High-sulfur kerogens (and coals) are almost always associated with marine deposition, because fresh waters are usually low in sulfate. Sulfur is only incorporated into kerogens in large quantities where sulfate reduction is extensive and where $\mathrm{Fe}^{2+}$ ions are absent (organic-rich, marine, nonclastic sediments). Many highsulfur kerogens are also high in nitrogen [21]. These findings further support the idea that Gilsonite is derived from lacustrine origin and not from marine origin. A plausible explanation for the difference in sulfur content between Gilsonite and oil shale kerogen might be that Gilsonite is neither oil nor tar, but a solid, degraded from shale oil kerogen that does not flow at normal temperatures and pressures, thus making it difficult to extract. Degradation of sulfur may occur when conventional liquid Gilsonite migrates toward the surface and encounters, at low temperatures, descending rainwater containing oxygen and bacteria. This leads to the formation of a Pitch-like substance poor in sulfur.

Oxygen: Preliminary examination of Table 2 reveals that oil shale kerogen exhibits the highest oxygen content ( $5.8 \mathrm{wt} . \%)$, followed by TLA (4.71 wt.\%), petroleum pitch (3.24 wt.\%), and then Gilsonite (1.36 wt.\%). These results throw some highlights on the degree of oxidation of each sample. It is very clear that the kerogen is the more highly oxidized bitumen among the others. As matter of fact, kerogen formation competes with the destruction of organic matter by oxidative processes. Most organic oxidation in sedimentary environments is microbially mediated. The mechanism of the oxidation of asphaltic materials can proceed along two paths: (1) the addition of oxygen to form unstable compounds from which water, carbon dioxide, or other unstable oxygen-containing substances are eliminated leaving unsaturated compounds which then polymerize, and (2) the addition of oxygen to form stable oxygenated compounds. Some deductions as to the possible oxidation mechanism for a bitumen such as Gilsonite can be made from elemental analyses of the material in various stage of weathering [18]. Previous studies have shown that the oxygen of Gilsonite may run from 0 to $2 \%$ [22]. Much of the oxygen appears as phenols with minor amounts of carboxylic acids. In his Bulletin no. 54, published in 1963, Dr. Crawford [18] detailed the chemical and physical properties of Gilsonite in parallel with other bitumen deposits. He showed that the oxygen content of Gilsonite is significantly influenced by its physical status. For instance, he indicated that in going from tar with $23 \%$ asphaltenes to some of the fresh samples of solid Gilsonite with 30 to $40 \%$ asphaltenes there is no appreciable increase in oxygen content. However, in going from the fresh solid to the more weathered solid forms of Gilsonite having from $40-70 \%$ asphaltenes, there is a definite increase in the oxygen content. He further added that the alteration of the more weathered forms of Gilsonite is a result of the formation of stable oxygenated compounds rather than of increased polymerization. Returning back to the Lake Pitch; the elevated oxygen content, however, was significant for TLA, indicating oxidation of the uppermost layer at the outcrop. The whole deposit is characterized by a high oxygen content as compared with Gilsonite. This may indicate exposure at or near the surface during early stages of development of the deposit. Note the high oxygen contents of TLA samples where oxidation has occurred, buried near the surface.

\section{Atomic ratio}

The atomic ratio of bitumen may indicate different stages of maturation $(\mathrm{C}, \mathrm{H})$, oxidation $(\mathrm{H}, \mathrm{O})$ or biodegradation $(\mathrm{H}, \mathrm{N}, \mathrm{S})$. 
Hydrogen-to carbon atomic ratio: The viscosity of bitumen is related to its hydrogen-to-carbon atomic ratio and hence the required supplementary heat energy for thermal extraction processes. It also affects the bitumen's distillation curve or thermodynamic characteristics, its gravity, and its pour point. Atomic hydrogen-tocarbon ratios as low as 1.3 have been observed for tar sand bitumen, although an atomic hydrogen-to-carbon ratio of 1.5 is more typical. The higher the hydrogen-carbon ratio of bitumen, the higher is its value as refinery feedstock because of the lower hydrogen requirements. Elements related to the hydrogen-carbon ratio are distillation curve, bitumen gravity, pour point, and bitumen viscosity [23]. Comparison of the data compiled in Table 2 shows that there is no significant difference between the H/C values of Gilsonite (1.44) and TLA (1.44). The H/C ratio for Gilsonite of the present study agrees very well with that for Gilsonite found by Hunt (1963) [14], of 1.42. This low atomic H/C ratio establishes its aromatic character. In one side, oil shale kerogen has the highest atomic $\mathrm{H} / \mathrm{C}$ ratio by 1.53 . Kerogens with such high atomic $\mathrm{H} / \mathrm{C}$ ratio generally possess excellent hydrocarbon resource potential [24]. Usually, the bitumens with high $\mathrm{H} / \mathrm{C}$ ratios are generally more soluble and fusible than those with low $\mathrm{H} / \mathrm{C}$ ratios. Solubility and fusibility are influenced by other factors, such as the sulfur, nitrogen, and oxygen content of the bitumens [25]. It has been demonstrated that the ratio of hydrogen to carbons atoms varies in different molecular structures. Naphthene and paraffin hydrocarbons have high H/C ratios whereas condensed aromatics have low $\mathrm{H} / \mathrm{C}$ ratios. Consequently, bituminous substances rich in the former materials have high $\mathrm{H} / \mathrm{C}$ ratios, whereas carbonaceous substances rich in the latter materials have low $\mathrm{H} / \mathrm{C}$ ratios [25]. In the other side, the petroleum pitch has the lowest atomic $\mathrm{H} / \mathrm{C}$ ratio compared to other bitumen materials. This can be taken as an additional indication of the higher maturity of the petroleum pitch samples as the H/C ratio of the bitumens decreases with increasing maturity.

Oxygen-to carbon atomic ratio: The oxygen-to-carbon ratio contains valuable information concerning the location of oil-and/or gas-bearing rock [26]. In Table 2 the $\mathrm{O} / \mathrm{C}$ ratios of different bitumen samples are listed. These ratios were in the range from 0.01 to 0.07 for Gilsonite and TLA, respectively. Generally speaking, this difference may be ascribed to the environment factors in which the bitumen was formed. Otherwise, prevalence of oxic or anoxic conditions at the bitumen interface during deposition appears to have effect on $\mathrm{O} / \mathrm{C}$ ratio. Taking into account that Gilsonite is derived from oil shale kerogen. Analysis of $\mathrm{O} / \mathrm{C}$ should be done on oil shale kerogen itself. Geochemists recognize Type I, II, III, and IV kerogens and classify these four types by optical and elemental criteria: Type I. Sapropelic $(\mathrm{H} /$ $\mathrm{C}>1.25 ; \mathrm{O} / \mathrm{C}<0.15)$, Type II. Planktonic $(\mathrm{H} / \mathrm{C}<1.25 ; 0.03<\mathrm{O} / \mathrm{C}<0.18)$, Type III. Humic $(\mathrm{H} / \mathrm{C}<1 ; 0.03<\mathrm{O} / \mathrm{C}<0.3)$, and Type IV Residue $(\mathrm{H} /$ $\mathrm{C}<0.5)$. These types of kerogen originate because of the different kinds of debris deposited in the sediment and also because of the conditions that prevail in that sediment over geological time [27]. Based on these criteria, it is apparent that the Gilsonite is originated from the Kerogen type I. It was reported that this type of kerogen is rich in lipid-derived aliphatic chains and has a relatively low content of polynuclear aromatic systems and of heteroatomic systems. This type of kerogen is generally of lacustrine origin. Organic sources for the type I kerogen include the lipid-rich products of algal blooms and the finely divided and extensively reworked lipid-rich biomass deposited in stable stratified lakes.

Carbon-to nitrogen atomic ratio: A useful application for $\mathrm{C} / \mathrm{N}$ ratios is as a proxy for paleoclimate research, having different uses whether the sediment cores are terrestrial-based or marine-based.
Carbon-to-nitrogen ratios are an indicator for nitrogen limitation of plants and other organisms and can identify whether molecules found in the sediment under study come from land-based or algal plants [28]. Further, they can distinguish between different land-based plants, depending on the type of photosynthesis they undergo. Therefore the $\mathrm{C} / \mathrm{N}$ ratio serves as a tool for understanding the sources of sedimentary organic matter, which can lead to information about the ecology, climate, and ocean circulation at different time in Earth's history [28]. Some work has been reported that if $\mathrm{C} / \mathrm{N}$ ratios in the range 4-10:1 are usually from marine sources, whereas higher ratios are likely to come from a terrestrial source $[29,30]$. The lack of cellulose, which has a chemical formula $\left(\mathrm{C}_{6} \mathrm{H}_{10} \mathrm{O}_{5}\right)_{n}$, and greater amount of proteins in algae versus vascular plants causes this significant difference in the $\mathrm{C} / \mathrm{N}$ $[28,31,32]$. The $\mathrm{C} / \mathrm{N}$ ratio of Gilsonite compared to various bitumens is shown in Table 2. All the bituminous samples exhibit higher $\mathrm{C} / \mathrm{N}$ atomic ratios; this signifies that they are of terrestrial origin. However, Gilsonite has the lowest $\mathrm{C} / \mathrm{N}$ ratio (39.05) compared to other bitumen specimens. As was stated in the literature [33], when composting microbial activity utilizes a $\mathrm{C} / \mathrm{N}$ ratio of 30-35:1 and higher ratio will result in slower composting rates. Thus, this implies that Gilsonite would be much easier to be decomposed by the microorganisms, being known as a more labile material. Moreover, it is worth mentioning that TLA from younger formations (Miocene era) [34] has higher ratio (140.75) than Gilsonite (39.05) from the older formations (Eocene and Oligocene eras) [35]. This suggests that the ratio is significant in assessing the age of a bitumen.

Sulfur-to carbon atomic ratio: Atomic S/C ratios are recorded in Table 2. The bitumen samples show $\mathrm{S} / \mathrm{C}$ ratios varying between 0.01 and 0.04 . This parameter declines to a lower value for Gilsonite bitumen (0.01). Studies by Hao et al. (2007) [36] have shown that solid bitumens from the marine carbonate reservoirs displayed atomic S/C ratios between 0.066 and 0.075 . However, solid bitumens from the nonmarine sandstones were relatively poor in sulfur with S/C ratios between 0.005 and 0.01. Likewise, Berner and Raiswell [37] suggested that nonmarine sediments were characterized by a low S/C ratio and marine sediments by a high $\mathrm{S} / \mathrm{C}$ value. Based on this data, Gilsonite from Uinta Basin may be also derived from nonmarine source. The differences in S/C ratios are more likely related to the increasing of bitumen alteration. Here, it should pointed out that the influences of many factors encountered in the bitumen, such as subsurface supply of sulfate from evaporitic minerals, $\mathrm{H}_{2} \mathrm{~S}$ mobility, and maturation of organic matter can significantly influence $\mathrm{S} / \mathrm{C}$ ratio.

\section{Heating value}

In routine terminology, the heating value of any fuel defined as the energy released per unit mass or per unit volume of the fuel when the fuel is completely burned [38]. The term calorific value is synonymous to the heating value. Typical units for expressing calorific or heating value are $\mathrm{MJ} / \mathrm{kg}$ in SI units or Btu/Lb (British thermal units per pound) in English units. The heating (calorific) value of natural bitumens is of great importance in the conversion of bitumen to other useful forms of fuel, as well as in its direct use. A formula for the gross heating value (HV) of natural bitumens was developed by Boie [39]. The empirical equation was expressed as follows: $\mathrm{HV}, \mathrm{Btu} / \mathrm{Lb}=1.8[8400(\mathrm{C})+27$ $765(\mathrm{H})+1500(\mathrm{~N})+2500(\mathrm{~S})-2650(\mathrm{O})]$. Table 2 shows measured gross heating values of Gilsonite and some selected bitumens. The results reveal remarkably big difference in the heating value of Gilsonite $(17,812 \mathrm{Btu} / \mathrm{Lb})$ and TLA $(10,627 \mathrm{Btu} / \mathrm{Lb})$. Based on organic matter of the bitumen, the heating values may vary. When the organic matter percentage is higher in a bitumen, the percentages of carbon and 


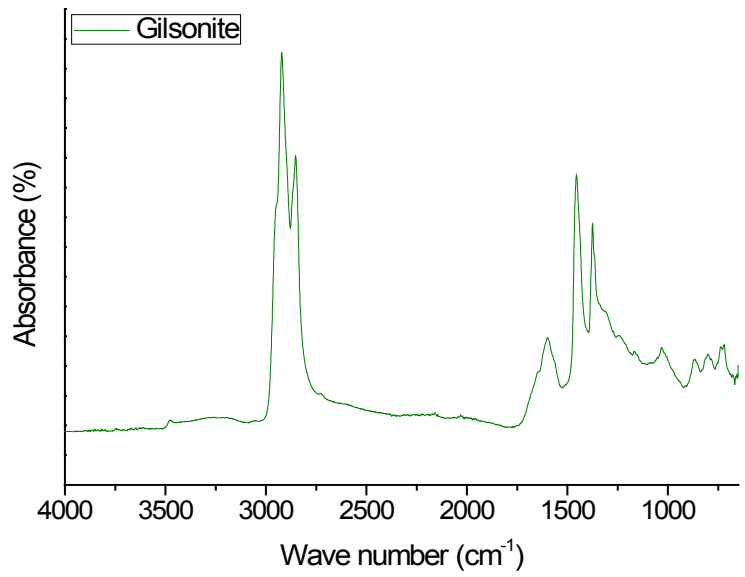

Figure 3: FTIR spectrum of Gilsonite.

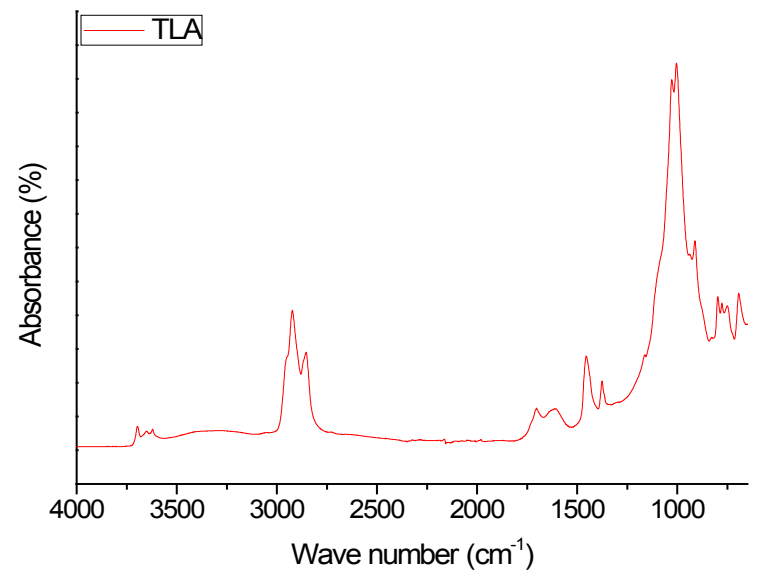

Figure 4: FTIR Spectrum of TLA.

hydrogen available for combustion are increased. This leads to the higher heating values.

Conclusions that can be drawn:

1- Differences in hydrogen, oxygen, nitrogen and sulfur contents between bitumen samples suggest that the sources of the organic matter are different.

2- Gilsonite in the Green River is probably derived partly from land types of organic material that form the Gilsonite and partly from plant and animal organisms that grew within the Green River itself.

\section{FTIR analysis}

Fourier transform (FTIR) spectroscopy is a powerful tool for characterization of bitumen and its products as it furnishes fast comprehensive view about the structure/ composition of the materials [40-45]. It is also a potential alternative method for acquiring qualitative mineralogy [46-48]. Infrared spectroscopy has not been utilized significantly in qualitative analysis of bitumen field minerals. The main uses have rather been in identification of minerals and in structural studies. Typical spectra of minerals display characteristic features which can be related qualitatively to variations in the constituent minerals. FTIR spectroscopy has recently been receiving attention for its potential use in mineral analysis. Figures 3 and Figure 4 compared with the standard patterns [48-52].

Band shapes for two samples show remarkable differences. The broad absorption bands observed between 3200 and $3600 \mathrm{~cm}^{-1}$ in the bitumens are due to $\mathrm{N}-\mathrm{H}$ and $\mathrm{O}-\mathrm{H}$ groups. The reported Gilsonite has greater pyrrolyic $\mathrm{N}-\mathrm{H}$ and hydrogen bonded $\mathrm{O}-\mathrm{H}$ or $\mathrm{N}-\mathrm{H}$ absorption than the TLA as revealed in the IR spectra. The main features of FTIR are the strong aliphatic absorptions; $2920 \mathrm{~cm}^{-1}$ and $2850 \mathrm{~cm}^{-1}$ due to asymmetric and symmetric $\mathrm{C}-\mathrm{H}$ stretching. The intensity of peak at $2920 \mathrm{~cm}^{-1}$ is greater than the peak at $2850 \mathrm{~cm}^{-1}$ for bitumens samples and indicates the presence of long aliphatic chains in Gilsonite. The pronounced aliphatic character is connected with their suitability for liquefaction. Medium intensity aromatic bands are observed in 900$690 \mathrm{~cm}^{-1}$ regions for TLA. The peaks near $1700 \mathrm{~cm}^{-1}$ appears in TLA indicating the presence of carbonyl $\mathrm{C}=\mathrm{O}$ contents. Band signals for the carbonyl stretching region of the TLA are more remarkable than those of Gilsonite. Suggesting that oxygen containing functional groups in TLA specifically; phenols, alcohols, ethers, carboxylic acid and carbonyls may exist in higher concentrations in TLA compared to Gilsonite. The two bands at 1455 and $1375 \mathrm{~cm}^{-1}$ are due to bending frequencies of (1) asymmetric $\mathrm{C}-\mathrm{CH}_{3}$ bond and/or methylene, and (2) symmetric $\mathrm{C}-\mathrm{CH}_{3}$ bond, respectively. These two peaks are more intense in Gilsonite than TLA. The region of $1000-1300 \mathrm{~cm}^{-1}$ observed in the spectra is for $\mathrm{C}-\mathrm{O}$ bonds in bitumen structures. The absorbance in this region is found to be decreased in case of Gilsonite bitumen. The weak band at $690 \mathrm{~cm}^{-1}$ observed in the bitumen may be due to C-S bond. As mentioned before, FTIR spectra may be used for the identification of minerals associated in the bitumen structures. There are observable distinguishing features in the spectra of the different natural bitumens. Prominent absorptions are apparent near 1000 and $1130 \mathrm{~cm}^{-1}$ for TLA. These intensive bands are attributed to $\mathrm{Si}-\mathrm{O}-\mathrm{Si}$ stretching vibrations for the tetrahedral sheets of kaolinite $[53,54]$. The absorption band due to bending vibration of inner $\mathrm{O}-\mathrm{H}$ groups was observed at $911 \mathrm{~cm}^{-1}$, while the inner-surface $\mathrm{OH}$ groups of kaolinite absorb at $936 \mathrm{~cm}^{-1}$. The broad OH-stretching band near $3620 \mathrm{~cm}^{-1}$ coupled with $829 \mathrm{~cm}^{-1}$, $749 \mathrm{~cm}^{-1}$ doublet indicates illite [49,55]. These bands originate from $\mathrm{Al}-\mathrm{Mg}-\mathrm{OH}$ deformation. Most of the weak peaks in FTIR spectra of natural bitumens near 1427, 875, 863 and $721 \mathrm{~cm}^{-1}$ can be assigned to carbonates (calcite, $\mathrm{CaCO}_{3}$; and dolomite, $\left.\mathrm{CaMg}\left(\mathrm{CO}_{3}\right)_{2}\right)$ [55,56]. The distinct doublet at $796 \mathrm{~cm}^{-1}$ and $777 \mathrm{~cm}^{-1}$ and the bands near 1163 and $692 \mathrm{~cm}^{-1}$ can be attributed to quartz in TLA samples [55]. These results show that the samples taken from Trinidad Island include illite, kaolinite, and quartz. However, Gilsonite seems very poor in mineral clays. The bitumens studied are found to be different in mineralogical compositions from FTIR analyses.

\section{TLC-FID analysis}

TLC-FID is becoming increasingly popular in the crude oil industry. This technique is recognized as an efficient, fast and costeffective way to obtain quantitative information about crude oil composition [57,58]. For separation and quantification, correct use of Iatroscan TLC-FID offers good precision and accuracy, in addition to rapid analysis and low solvent consumption. The TLC-FID testing procedure was chosen similar to the one outlined in [59]. Thin layer chromatography with Iatroscan instrument separates natural bitumen into saturate, aromatic, resin and polar fractions. Figure 5 illustrates typical TLC-FID chromatograms of Gilsonite and TLA.

It can be seen very clearly from Figures 5 and 6 that the chemical composition of natural bitumen samples from Uinta basin and Trinidad 


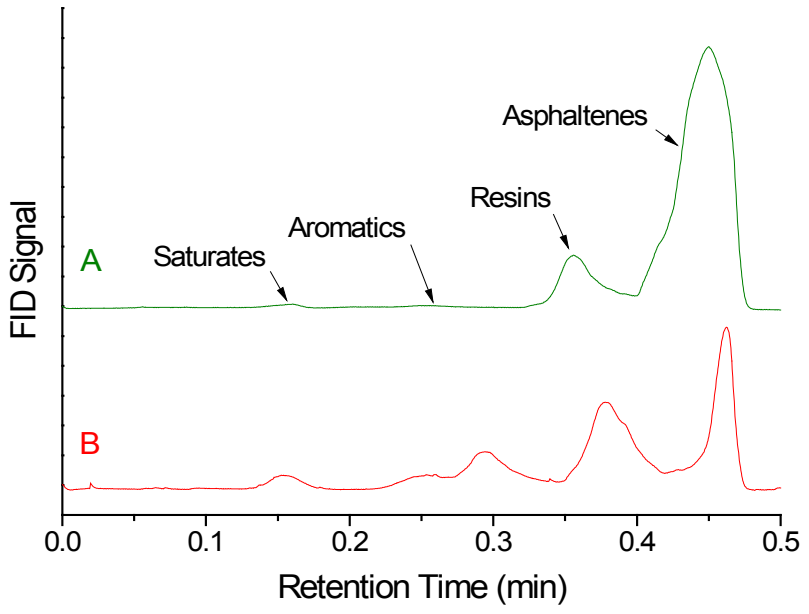

Figure 5: TLC-FID chromatograms of Gilsonite (A) and TLA (B).

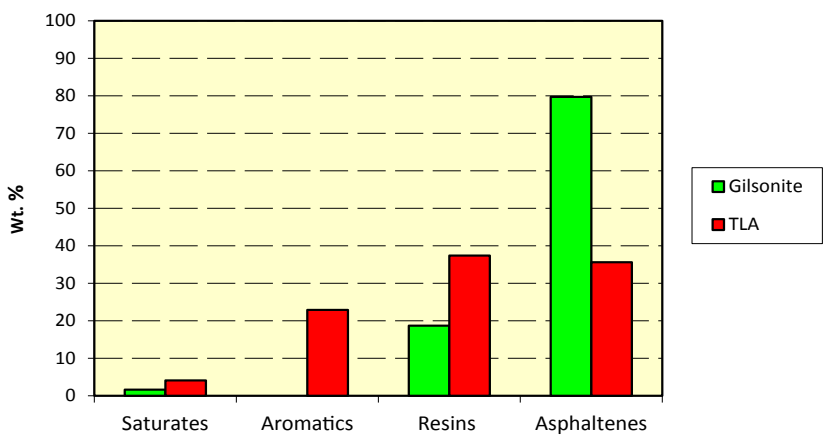

Figure 6: Diagram of SARA separation for Gilsonite and TLA

Island differ considerably. The TLA samples are highest in saturates contents (4.1 wt.\%) indicating their paraffinic characteristics, while the Gilsonite sample is lowest in saturates content (1.6 wt.\%) suggesting its naphthenic characteristics. Aromatics hydrocarbon yields are highest in the TLA (22.9 wt.\%) and negligible for Gilsonite (0 wt.\%). The resin fractions in TLA (37.4 wt.\%) are found to be more significant than those in Gilsonite (18.7 wt.\%). The asphaltenes yields in Gilsonite are almost two times higher (79.7 wt.\%) than the TLA (35.6 wt.\%).

The compositional profile of bitumen components varies substantially depending on the sample and its origin. The solvent system affects the separation efficiency of bitumen components on chromarod. Selection of the solvent is generally guided by the polarity of the analytes. Representative chromatograms of the two natural bitumen samples are shown in Figure 5. It is obvious that there are some differences between the two chromatograms. The magnitude of the differences depends on the nature of the bitumen. Figure 5(B) demonstrates the capability of TLC-FID for the resolution of saturates, aromatics, and of the ring-based separation of aromatic compounds, as well as the resins compounds. The four different peaks displayed in Figure 5(B) are identified as: saturates, aromatics, resins and asphaltenes (SARA). A cursory examination of chromatograms of Gilsonite in Figure 5(A) and TLA in Figure 5(B) suggests a marked compositional difference between these two samples. Note that TLA was derived from Trinidad Island. TLA contains less polar and large ring aromatic compounds than Gilsonite. However, Gilsonite seems devoid of any aromatic at all; the considered material exhibits no pronounced aromatics peak in the chromatogram (Figure 5(A)).

On one hand, the most interesting finding is the marked highest asphaltenes amount and the nil aromatics content detected in Gilsonite, which is most unusual for a natural bitumen. It appears that during the genesis of Gilsonite, it was severely affected by the process of oxidation coming from several factors such as higher temperatures, higher pressures, leaching by superficial and underground water, atmospheric oxygen, UV radiation, biodegradation...etc. Taken together, these factors may lead to convert much more amount of aromatics and resins to asphaltenes. Thus, this fact would justify the observed increasing in asphaltenes compounds. On the other hand, it must be realized that the primary cause of saturates reduction is simply a loss of light hydrocarbons gases from the Gilsonite before its solidification. This loss of hydrocarbons is usually a result of changes in temperature and pressure in depth of earth. The saturates that have the lowest melting point and molecular weight are usually the first to separate from liquid Gilsonite. Here, it can be concluded that the distinct differences in the natural bitumens are due to the differences in the structural units forming the constituent groups, the location, the depth, and the history of each deposit formation. Last but not least, it must be pointed out that the Gilsonite is indeed largely nonaromatic then its use for road pavement is likely to have important health and environmental advantages over the use of petroleum pitches which characteristically have a high content of polynuclear aromatic hydrocarbons.

\section{Chemical nature of Gilsonite}

Gilsonite is a complex system of different constituents, made of hydrocarbons and heteroatoms. After fractionation of the Gilsonite by specific solvents, four main chemical families are obtained: saturates, aromatics, resins, and asphaltenes. The association of asphaltene sheets (highly polycondensed pseudomonomers of a carbon black-bone, chemical functions and heteroatoms surrounded by aliphatic chains) leads to formation of macrostructures or "micelles". They can also form aggregates. The different constituents in the bitumen follow a colloidal law, expressed by the following relationship (2):

$$
\text { CII }=\frac{\text { flocculated constituent }}{\text { dispersed constituent }}=\frac{\text { saturates }+ \text { asphaltenes }}{\text { resins }+ \text { aromatics }}
$$

Empirical evidence has shown that values of 0.9 and more indicate bitumen with unstable asphaltene, while values below 0.7 indicate stable asphaltenes. Between 0.7 and 0.9 , the stability of the asphaltenes is uncertain [8]. The CII values of the two bitumen samples were calculated by the SARA method. As shown in Table 3, the CII value of Gilsonite was greater than 0.9 , indicating that in this bitumen sample asphaltene deposition tends to occur due to its higher asphaltenes content and lower aromatics and resins contents. Conversely, the CII value of TLA was relatively smaller than 0.7 , which is typical of pavinggrade bitumen, and supports the observation that TLA has a more dispersed structure than Gilsonite. Here, it is important to note that the instability of Gilsonite, originating mostly from cracking/ visbreaking processes, tend to form free radicals, leading to polymerization chain reactions that result ultimately in formation of degradation products [60].

\section{${ }^{1} \mathrm{H}$ NMR analysis}

Recently, hydrogen nuclear magnetic resonance ( $\left.{ }^{1} \mathrm{H} \quad \mathrm{NMR}\right)$ spectroscopy has emerged as a very powerful and versatile tool for bitumen characterization $[40,61,62] .{ }^{1} \mathrm{H}$ NMR allows the investigations 


\begin{tabular}{|c|c|c|}
\hline \multirow{2}{*}{ Components } & \multicolumn{2}{|c|}{ Natural bitumen } \\
\cline { 2 - 3 } & Gilsonite & TLA \\
\hline Saturates, wt. \% & 1.6 & 4.1 \\
\hline Aromatics, wt. \% & 0 & 22.9 \\
\hline Resins, wt. \% & 18.7 & 37.4 \\
\hline Asphaltenes, wt. \% & 79.7 & 35.6 \\
\hline Colloidal instability index, Cll & 4.34 & 0.65 \\
\hline Stability & Very unstable & Stable \\
\hline
\end{tabular}

Table 3: Stability of natural bitumens.

\begin{tabular}{|c|c|c|c|c|}
\hline \multirow{2}{*}{ Natural bitumen } & \multicolumn{4}{|c|}{ Hydrogen distribution } \\
\cline { 2 - 5 } & $\mathbf{H}_{\alpha}$ & $\mathbf{H}_{\boldsymbol{\beta}}$ & $\mathbf{H}_{\boldsymbol{\gamma}}$ & $\mathbf{H}_{\mathrm{ar}}$ \\
\hline Gilsonite & 13.45 & 52.45 & 29.49 & 4.62 \\
\hline TLA & 16.34 & 51.95 & 25.43 & 6.29 \\
\hline
\end{tabular}

Table 4: Fractional proton distribution of natural bitumens.

\section{Gilsonite}

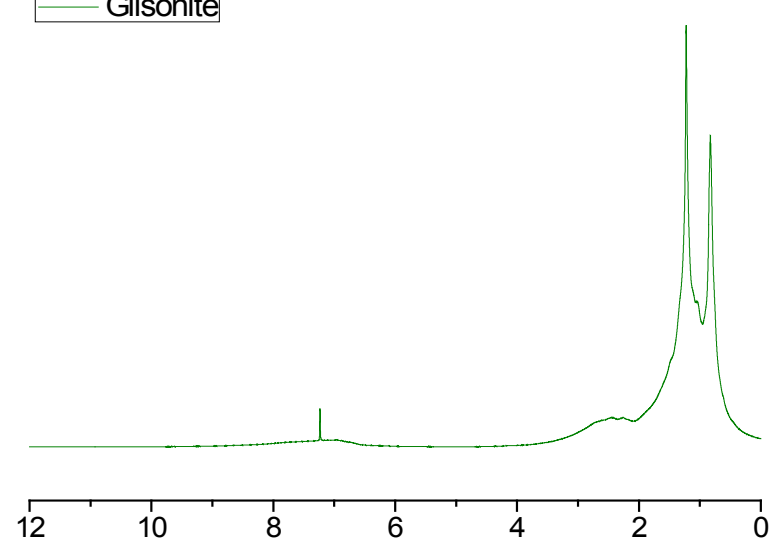

Figure 7: ${ }^{1} \mathrm{H}$ NMR spectrum of Gilsonite.

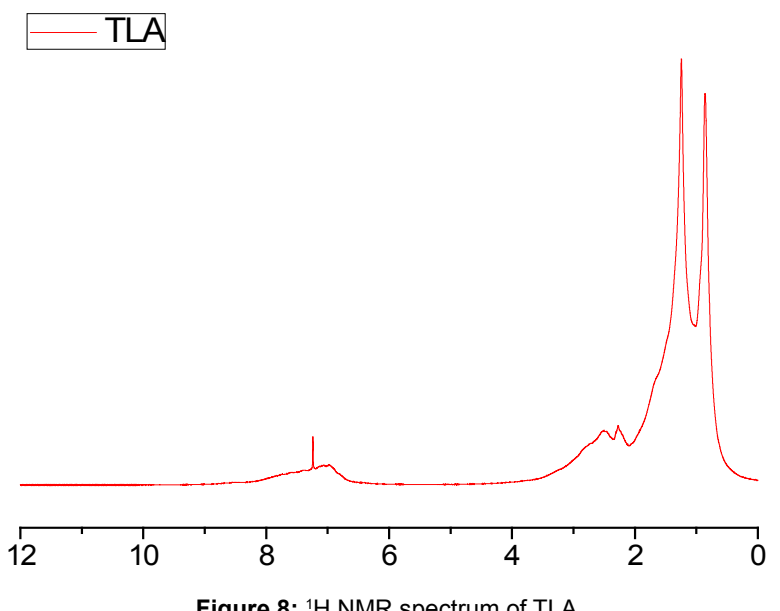

Figure 8: ${ }^{1} \mathrm{H}$ NMR spectrum of TLA.

in solids as well as in solution. As an alternative to the conventional analysis, ${ }^{1} \mathrm{H}$ NMR spectrometry methods does not require sample pretreatment and thus reduces considerably manipulation time. It is also considered environmentally friendly as it enables the use of minimum amount of solvents with practically no waste generation compared, for instance, to chromatographic methods. ${ }^{1} \mathrm{H}$ NMR method is also capable of simultaneously detecting and quantifying a number of constituents in a single spectrum. The direct ${ }^{1} \mathrm{H}$ NMR spectrometry quantitative method presents advantages over some routine methods: simplicity; rapidity; selective recognition; and quantitative determination of aliphatic hydrogens and aromatic hydrogens in bitumen. The ${ }^{1} \mathrm{H}$ NMR spectra of Gilsonite and TLA are shown in Figures 7 and 8, respectively.

If contributions from protons associated with heteroatoms can be discounted, proton types in the NMR spectra can be divided into four groups: aromatic protons $\left(\mathrm{H}_{\mathrm{ar}} ; 6.0\right.$ to $\left.9.0 \mathrm{ppm}\right)$, alpha alkyl protons $\left(\mathrm{H}_{\alpha} ; 2.0\right.$ to $\left.4.0 \mathrm{ppm}\right)$, methyl protons in the gamma position or farther from the aromatic ring $\left(\mathrm{H}_{\gamma} ; 0.5\right.$ to $\left.1.0 \mathrm{ppm}\right)$ and other alkyl protons representing primarily the methylene protons which are beta or farther from the aromatic ring $\left(\mathrm{H}_{\beta} ; 1.0\right.$ to $\left.2.0 \mathrm{ppm}\right)$ [63]. Fractional proton distributions were calculated directly from the integration curves. The separation point was chosen semi-empirically for the $\mathrm{H}_{\alpha}$ and $\mathrm{H}_{\beta}$ bands at $1.9 \mathrm{ppm}$ and for the $\mathrm{H}_{\beta}$ and $\mathrm{H}_{\gamma}$ bands at $1.0 \mathrm{ppm}$ from the determination of the band shapes and areas. Fractional proton distributions of the two bitumen samples are presented in Table 4.

According to Figures 7 and 8, it can be said that approximately similar chemical compounds exist in all natural bitumen samples. Both samples contained two very strong absorption peaks at 0.84 and 1.23 ppm, which correspond to protons on methyl and methylene groups, respectively. The ${ }^{1} \mathrm{H}$ NMR spectrum confirms that Gilsonite has a negligible concentration of aromatic compounds. Helms and co-workers (2012) [64-67] have reported similar findings on a typical Gilsonite sample, collected in the Uinta Basin near the town of Bonanza, Utah. The bumps observed in the 6.8-8.0 ppm region for TLA are attributed to the presence of aromatics. This implies that the aromatic hydrogen in these bitumens belongs to mono- di- polyaromatic structures. The TLC-FID chromatogram of TLA matches very well with this observation. The sharp peak at $7.2 \mathrm{ppm}$ is due to exchanged protons on the deuterated chloroform solvent. The absence of resonance bands in the 4.5-6.3 ppm region indicates that the natural bitumens contain a negligible quantity of double bonds representing olefinic hydrocarbons.

As depicted in Table 4, the Gilsonite and TLA have an overall similar distribution of hydrogen types. This means that the nature of the compounds forming all these samples is pretty similar. They show a high proportion of aliphatic hydrogens (93.71 vs. 95.38\%) corresponding most of them to $\mathrm{H}_{\beta}(51.95$ vs. $52.45 \%)$ and lower concentration of aromatic hydrogens (4.62 vs. $6.29 \%$ ). In spite of the similarity among the samples some differences can be stored out. It is observed that the composition of Gilsonite is slightly rich in methylene hydrogens $\left(\mathrm{H}_{\beta}\right)$ but have less aromatic and a hydrogens to aromatic rings. Then it could be expected longer chain length in Gilsonite referred to TLA and less alkyl substitutions attached to aromatic rings.

\section{Conclusion}

The Gilsonite in this study can be related geochemically to the oil shale kerogen from the Green River formation. The elemental analysis indicated noticeably that carbon (84.36 wt.\%), and some amounts of hydrogen (10.05 wt.\%) predominantly compose the Gilsonite. The content of oxygen (1.36 wt.\%) and sulfur (0.27 wt.\%) was quite small. However, the nitrogen content was significantly high (3.25 wt.\%). The low H/C atomic ratio (1.44) established the aromatic character of Gilsonite. Solvent extraction technique showed that Gilsonite was made up of $99.32 \%$ of organic matter and $0.68 \%$ of inorganic matter. Iatroscan TLC-FID was used as an accurate way to obtain a preliminary description of Gilsonite information. In one side, this technique confirmed that Uintaite consists primarily of resins (18.7 wt.\%) and asphaltenes (79.7 
wt.\%). In other side, it predicted that Uintaite is rheologically instable $(\mathrm{CII}=4.34)$. Infrared spectrum demonstrated not only, more intense bands assigned to aliphatic than to aromatic structures; indicating a more aliphatic character. But also, showed some weak bands attributed to mineral clays. The quantitative analysis of ${ }^{1} \mathrm{H}$ NMR data appeared to be a valuable tool to predict some possible structural arrangements in natural bitumen. It has highlighted that Gilsonite comprises $13.45 \%$ $\mathrm{H}_{\alpha} ; 52.45 \% \mathrm{H}_{\beta} ; 29.49 \% \mathrm{H}_{\gamma}$; and $4.62 \% \mathrm{H}_{\mathrm{ar}}$. In short, it can be said that after modification, Gilsonite may be considered a valuable component for use as material for road construction, waterproofing and roofing. Moreover, it may be directly used as fuels for industrial furnaces, power plant and boilers. This work has given impetus for further characterization of the Gilsonite present in the Uinta Basin based on its physical and rheological properties; further facies characterization may include: softening point, penetration, viscosity, ductility, and flash point tests.

\section{Acknowledgment}

This work was sponsored by grants from the Cooperative R\&D Program funded by The Ministry of Knowledge Economy and Korea Research Council for Industrial Science \& Technology. The principal author would like to thank Pr. Namjun Cho and Pr. Kim Namho of Korea University of Technology and Education for their contribution to the project.

\section{References}

1. Gillson JL (1960) Industrial Minerals and Rocks: Nonmetallics Other Than Fuels, The American Institute of Mining, Metallurgical, and Petroleum Engineers, New York, USA

2. Gilsonite: Comes of Age (August 1990) VENews-Venture Chemicals, LA, USA.

3. Keighin CW, Hibpshman MH (1975) Preliminary Mineral Resource Study of the Uintah and Ouray Reservation, Utah, Technical Report No. 4, Bureau of Indian Affairs, Utah.

4. Jackson D (1985) American Gilsonite: Mining Solid Hydrocarbon in Geology and energy resources, Picard MD (editor) Utah Geological Association, Uinta Basin of Utah, USA 12: 257-261.

5. Kretchman HF (1957) The story of Gilsonite: Salt Lake City, Utah, American Gilsonite Company.

6. Covington RE (1964) A brief history of early mineral exploitation in the Uinta Basin in Geology and mineral resources of the Uinta Basin, Utah's hydrocarbon storehouse, Eighth Annual Field Conference: Intermountain Association of Petroleum Geologists, Utah, Sabatka EF (editor) Utah Geological Association, Utah.

7. Pruitt RG (1961) The mineral resources of Utah County, Bulletin No. 71, Utah Geological and Mineralogical Survey, USA.

8. Gaestel C, Smadja R, Lamminan KA (1971) Contribution a la connaissance des propriétés des bitumes routiers. Rev. Gén. Routes Aérodromes, 466: 85-94.

9. Carman EP, Bayes FS (1961) Occurrence, properties, and uses of some natural bitumens; Technical Report No. 7997, Dept. of the Interior, Bureau of Mines: (Washington) U.S

10. Boden T, Tripp BT (2012) Gilsonite Veins of the Uinta Basin, Utah. Report No. 141, Utah Geological Survey, Salt Lake City, Utah, USA.

11. http://www.gilsonite-bitumen.com

12. Peters KE, Walters CC, Moldowan JM (2005) The Biomarker Guide, Biomarkers and Isotopes in Petroleum Exploration and Earth History, Cambridge University Press, United Kingdom.

13. Monson B, Parnell J (1992) The origin of Gilsonite vein deposits in the Uinta Basin, Utah in Hydrocarbon and Mineral Resources of the Uinta Basin, Utah and Colorado, Guidebook 20, Fouch TD, Nuccio VF, Chidsey TC (editors) Utah Geological Association, Salt Lake City, 257-270.

14. Hunt JM (1963) Composition and origin of the Uinta Basin Bitumens, Bulletin No. 54, Utah Geological and Mineralogical Survey, Salt Lake City, Utah 249273.

15. Letcher TM. Future Energy: Improved, Sustainable and Clean Options for our Planet, Elsevier Science, UK.
16. Stangl K, Jäger A, Lackner B (2006) Microstructure-based identification of bitumen performance. Road Materials and Pavement Design. EATA 7: 111-142.

17. http://www.zieglerchemical.com.

18. Crawford AL, Pruitt RG (1963) Gilsonite and other bituminous resources of central Uintah County, Utah in Oil and Gas Possibilities of Utah-Re-evaluated Bulletin 54, Crawford AL (editor) Utah Geological and Mineralogical Survey, Salt Lake City, USA

19. McGee LR (1956) Porphyrins in Gilsonite. PhD Thesis, University of Utah, Salt Lake, Utah, USA.

20. Yasin G, Bhanger MI, Ansari TM, Muhammad S, Naqvi SR, et al. (2013) Quality and chemistry of crude oils. Journal of Petroleum Technology and Alternative Fuels, 4: 53-63.

21. Vandenbroucke M, Largeau C (2007) Kerogen origin, evolution and structure Organic Geochemistry 38: 719-833.

22. Fieser LF, Jacobsen RP (1936) Precision Combustion of Natural Products. J Am. Chem. Soc. Jour., 57: 943-946

23. Speight JG (2006) The chemistry and Technology of Petroleum, CRC Press, USA.

24. Andres DE, Palacas JG, Johnson RC (1992) Thermal maturity of rocks and hydrocarbon deposits, Uinta Basin, Utah in Hydrocarbon and mineral resources of the Uinta Basin, Utah and Colorado: Utah Geological Association Guidebook Fouch TD, Nuccio VF, Chidsey TC (editors) Utah Geological Association, USA No. 20: 53-74.

25. Arthur LC (1963) Oil and Gas Possibilities of Utah, Re-evaluated, Utah Geological and Mineralogical Survey, USA.

26. Roscoe BA, Grau JA (1985) Response of the Carbon/Oxygen Measurement for an Inelastic Gamma Ray Spectroscopy Tool in Society of Petroleum Engineers, 60th Annual Technical Conference and Exhibition of the Society of Petroleum Engineers, Las Vegas, NV, USA.

27. Speight JG (2011) Handbook of Industrial Hydrocarbon Processes, Gulf Professional, UK.

28. Ishiwatari R, Uzaki M (1987) Diagenetic Changes of Lignin Compounds in a More than 0.6 Million-Year-Old Lacustrine Sediment (Lake Biwa, Japan). Geochimica Et Cosmochimica Acta, 51: 321-328.

29. Gray KR, Biddlestone AJ (1973) Composting- process parameters. The Chemical Engineer 2: 71-76.

30. Keith S (2006) It's A Long Road to A Tomato, Marlowe \& Company, New York USA.

31. Müller PJ (1977) CN ratios in Pacific deep-sea sediments: Effect of inorganic ammonium and organic nitrogen compounds sorbed by clays. Geochimica ET Cosmochimica Acta 41: 765-776.

32. Meyers PA, Doose H (1999) Sources, Preservation, and Thermal Maturity of Organic Matter in Pliocene-Pleistocene Organic-Carbon-Rich Sediments of the Western Mediterranean Sea in Proceedings of the Ocean Drilling Program Scientific results, Zahn R, Comas MC, Kraus A (editors), 161: 383-390.

33. Prahl FG, Ertel JR, Goni MA, Sparrow MA, Eversmeyer B (1994) Terrestrial Organic-Carbon Contributions to Sediments on the Washington Margin. Geochimica Et Cosmochimica 58: 3035-3048.

34. Kumar A (2012) La Brea Pitch Lake and Mud Volcanoes of Trinidad, West Indies. Earth Science India Popular Issue 2: 1-10.

35. Crawford AL (1949) Gilsonite and Related Hydrocarbons of the Uinta Basin Utah. Technical Report, Utah Geological and Mineral Survey, Salt Lake City, Utah, USA.

36. Hao F, Guo T, Zhu Y, Cai X, Zou H, et al. (2008) Evidence for multiple stages of oil craking and thermochemical sulfate reduction in the Puguang gas field, Sichuan Basin, China. AAPG Bulletin 92: 611-637

37. Berner RA, Raiswell R (1983) Burial of Organic Carbon and pyrite Sulfur in Sediments over Phanerozoic Time: a New Theory. Geochimica et Cosmochimica Acta 47: 855-862

38. ASABE Standards (2011) American Society for Agricultural \& Biological Engineers, St. Joseph, MI: ASABE.

39. Boie W (1952) Contributions to Pyrotechnic Computations Wessinschftliche Zeitschrift der Technischen Hochschule, Dresden 2: 687-718. 
Citation: Nciri N, Song S, Kim N, Cho N (2014) Chemical Characterization of Gilsonite Bitumen. J Pet Environ Biotechnol 5: 193. doi:10.4172/21577463.1000193

Page 10 of 10

40. Jain PK, Tyagi OS, Singh H (1998) Physico-Chemical and Compositional aspects of Bitumen Bearing Crudes and Their Instrumental Characterization. Petroleum Science and Technology 16: 567-582.

41. Painter P, Williams $P$, Mannebach E (2004) Recovery of Bitumen from Oil or Tar Sands Using lonic Liquids. Energy Fuels 24: 1094-1098.

42. Mouillet V, Farcas F, Besson S (2008) Ageing by UV radiation of an elastomer modified bitumen. Fuel 87: 2408-2419.

43. Yoon S, Bhatt SD, Lee W, Lee HY, Jeong SY, et al. (2009) Separation and characterization of bitumen from Athabasca oil sand. Korean. Chem. Eng. 26: 64-71.

44. Guern ML, Chailleux E, Farcas F, Dreessen S, Mabille I (2010) Physicochemical analysis of five hard bitumens: Identification of chemical species and molecular organization before and after artificial aging. Fuel 89: 3330-3339.

45. Reena G, Sangita, Verinder K (2012) Characterization of Bitumen and Modified Bitumen (e-PMB) using FT-IR, Thermal and SEM techniques. Research Journal of Chemical Sciences 2: 31-36.

46. Madejová J (2003) FTIR techniques in clay mineral studies. Vibrational Spectroscopy 31: 1-10.

47. Schäfer T, Michel P, Claret F, Beetz T, Wirick S, et al. (2009) Radiation sensitivity of natural organic matter: Clay mineral association effects in the Callovo-Oxfordian argillite. Journal of Electron Spectroscopy and Related Phenomena 170: 49-56.

48. Liu Q, Yao X, Cheng H, Frost RL (2012) An infrared spectroscopic comparison of four Chinese palygorskites. Spectrochimia Acta Part A: Molecular and Biomolecular Spectroscopy 96: 784-789.

49. Vaculíková L, Plevová E (2005) Identification of clay minerals and micas in sedimentary rocks. Acta Geodyn. Geomater. 2: 167-175.

50. Nayak PS, Singh BK (2007) Instrumental characterization of clay by XRF, XRD and FTIR. Bull. Mater. Sci. 30: 235-238.

51. Yoon S, Son J, Lee W, Lee W, Lee H, et al. (2009) Prediction of bitumen content in oil sand based on FT-IR measurement. Journal of Industrial and Engineering Chemistry 15: 370-374.

52. Osacky M, Geramian M, Dyar MD, Sklute EC, Valter M, et al. (2013) Characterization of Petrologic End Members of Oil Sands From The Athabasca Region, Alberta, Canada. The Canadian Journal of Chemical Engineering 9999: 1-14.

53. Lee SA (1960) Infrared spectra-structure correlations of organosilicon compounds. Spectrochimica Acta 16: 87-105.

54. Masooleh MS, Bazgir S, Tamizifar M, Nemati A (2010) Adsorption of petroleum hydrocarbons on organoclay. Journal of Applied Chemical Researches 4: 1923.

55. Davarcioğlu B, Çiftçi E (2009) Investigation of Central Anatolian Clays by FTIR Spectroscopy (Arapli-Yesilhisar-Kayseri, Turkey). International Journal of Natural and Engineering Sciences, 3: 167-174.

56. Ji J, Ge Y, Balsam W, Damuth JE, Chen J (2009) Rapid identification of dolomite using a Fourier Transform Infrared Spectrophometer (FTIR): A fast method for identifying Heinrich events in IODP Site U1308. Marine Geology 258: 60-68.
57. Tonegawa T, Ikoma T, Yoshioka T, Hanagata N, Tanaka J (2010) Crystal structure refinement of A-type carbonate apatite by $\mathrm{X}$-ray powder diffraction. $\mathrm{J}$ Mater Sci 45: 2419-2426.

58. Ray JE, Oliver KM, Wainwright JC (1982) In Petroanalysis 81. IP Symposium, London, Heyden \& Son, UK, 361-388.

59. Higuerey I, Orea M, Pereira P (2002) Estimation of visbroken and selective catalytic steam cracked product stability using latroscan TLC-FID. Fuel Chemistry Division Preprints 47: 656-658.

60. Speight JG (1997) Petroleum Chemistry and Refining, CRC Press, USA.

61. Borrego AG, Blanco CG, Prado JG, Díaz C, Guillén MD (1996) ${ }^{1} \mathrm{H}$ NMR and FTIR Spectroscopic Studies of Bitumen and Shale Oil from Selected Spanish Oil Shales. Energy Fuels 10: 77-84.

62. Woods JR, Kung D, Kingston D, McCracken T, Koltlyar LS, et al . (2012) Comparison of Bitumens From Oil Sands with Different Recovery Profiles. Petroleum Science and Technology 30: 2285-2293.

63. Zander M (2000) Chemistry and properties of coal-tar and petroleum pitch in Sciences of carbon materials, Marsh $\mathrm{H}$, Rodríguez-Reinoso $\mathrm{F}$ (editors) Universidad de Alicante, Secretariado de Publicaciones 205-257.

64. Helms JR, Kong X, Salmon E, Hatcher PG, Schmidt-Rohr K (2012) Structural characterization of gilsonite bitumen by advanced nuclear magnetic resonance spectroscopy and ultrahigh resolution mass spectroscopy revealing pyrrolyic and aromatic rings substituted with aliphatic chains. Organic Geochemistry 44: 21-36.

65. Nciri N, Song S, Kim N, Cho N (2014) Comparison of Chemical Properties of Trinidad Lake Asphalt and Asphalt Ridge bitumen. (Under publication).

66. Nciri N, Song S, Kim N, Cho N (2013) Physicochemical Characterization of Asphalt Ridge Froth Bitumen and Petroleum Pitch. International Journal of Chemical, Environmental \& Biological Sciences 1: 749-756.

67. Fenton DM, Hennig H, Richardson RL (1980) The Chemistry of Shale Oil and its Refined Products in American Chemical Society Meeting. 2. Chemical Congress of the North American Continent, Las Vegas, NV, USA, Am. Chem. Soc. Div. Fuel Chem 102-109. 